\title{
THE HELDERBERG ADVOCATE
}

\author{
BY DONALD F. CAMERON \\ Librarian of the University
}

THE LIBRARY has been fortunate enough to acquire a run of the Helder berg Advocate, Volume I, No. I through

1 Volume III, No. 23 (September I, I84I-August I6, I843). This rare newspaper was published every other Wednesday at Bern, Albany County, New York, and at Schoharie Court House, New York, "Printed for the Committee" by William H. Gallup, Schoharie Court House.

The Advocate is an interesting episode in the anti-rent war waged by the tenants of the Van Rensselaers of upstate New York for several generations until finally the matter was settled in the I 860's.

The term "Printed for the Committee" means that a group of self appointed individuals had decided to publicize their cause throughout Albany County in the I $840^{\circ}$ 's in order to bring to the attention of the politicians in Albany the oppressive terms of the contracts under which they held their land. The last of the patroons, Stephen Van Rensselaer, was the object of their attack, and the contracts which were reprinted in this paper served to stir up public feeling.

The paper enjoyed a short stormy life. The publisher, William $\mathrm{H}$. Gallup, was also the publisher of The Schoharie Republican, a more conventional newspaper. The publisher was threatened with suit. As a result the paper was abandoned in August, I 843, in order to save The Schoharie Republican, a more lucrative venture whose existence was threatened also.

The war between the tenants and the Patroon and other great landlords was continuous for 40 years, but varied in intensity. The period of the Advocate represents one of activity and even violence.

The terms under which the tenants held the land seem now to be very strange. The leases of 1840 indicate that the tenant had the use of the land within the Manor of Rensselaerwyck for a rent, either in cash or kind. He did not have any rights to "creeks, kills, or runs of water," nor did he have right to any minerals which might be found on the land. The patroon also reserved rights to wood, fire-wood, and timber for the repair of such mills as the patroon erected.

The tenant likewise was hampered in any attempt to sell his land, and in general if he sold, the proprietors were entitled to $25 \%$ of the 
price. It is strange to think that any considerable part of the population of the State of New York continued to live under these conditions until past the middle of the I 9 th Century.

The chief interest in the Helderberg Advocate is in the lively account it gives of the efforts of the indignant tenants of the land southwest of Albany to resist evictions, and to bring to the attention of the politicians in Albany, the antiquated land tenure under which they were forced to live. Long after the Advocate was a memory, conditions were finally changed as a result of the efforts of Governor Seward and the new radicals who were later to form the Republican party.

The leading name connected with the Helderberg Advocate was not a native of the State of New York. He was an Irishman by the name of Thomas Ainge Devyr who had made himself unpopular in England in the 1830's, because of his activity in behalf of the coal miners. He found it wise to leave England and came to America expecting to find an agrarian Utopia inhabited entirely by strong, self-reliant, independent farmers. He was essentially a crusading journalist, and when he found out the conditions under which the people were living in upstate New York, he immediately espoused their cause declaring conditions under which they held land even worse than the conditions he had fought against as a member of the Chartist movement in England.

Devyr quickly became a spokesman in Albany County. He traveled from Westchester County to appear at picnics and kept a steady stream of material flowing from his pen to the Helderberg AdvoCATE. It is not difficult to identify his fiery style in the editorials, nor is it hard to see his hand in the appearance of news from Europe which along with advertisements and clippings from other newspapers make up the bulk of each issue. It is a question whether the farmers by themselves would have resisted so openly the claims of the patroon had it not been for Devyr and some other individuals. On the rocky slopes of the Helderberg Mountains, farmers regarded the rents which they paid for their sterile acres as too high. During the life-time of Stephen Van Rensselaer's father, rents had not been regularly collected. After his death, however, the estate endeavored to collect not only the current rent but also the back rent, and to enforce many of the provisions of the leases which had not been in force in many years. Many of the farmers refused to pay back rent and resisted eviction. The patroon's agents were threatened with 
violence, and on one inglorious occasion had come to the HeLderBERGS escorted by a company of militia from Albany.

It soon became apparent that the Devyr doctrine of resistance was going to lead to serious trouble. Here was Devyr, a doctrinaire radical with a facile pen and an undoubted grip upon the emotions of the people. They could easily understand the indignation which he shared with them at the injustices of the leases. However, the farmers of that part of the world by no means shared Devyr's interest in anything as abstract as "the rights of man." They were a very conservative group of farmers who found themselves trapped by an outmoded system of land tenure. They were not philosophers, nor were they interested in politics except insofar as politics might relieve them of their present burdens. The inevitable split came, and Devyr left that part of the country in order not to jeopardize the program of the anti-rent party. As the Advocate comes to its close in I 843 , it becomes less violent in its views and comes to be more of an ordinary newspaper. There were frequent appeals to the subscribers to pay their subscriptions. The threat of the removal of the political advertisements from The Schoharie Republican also hastened the death of the Advocate. This occurred with Volume III, No. 23. The last issue has lost the fire of the first one. It contains a reprint of the Life of Aaron Burr, an anecdote about the Negroes in Kentucky, and an account of a violent gale and thunderstorm at Philadelphia. There is a note about the close of the "Florida War," some social notes from Bern and Howe's Cave, advertisements for patent medicines, and an article on architecture in the ancient world. In this issue there is not a word about rents, nor about injustice, nor any mention of the patroon. 